\title{
デイサービスセンターにおける共用空間に対する評価構造 EVALUATION STRUCTURE OF COMMON SPACE IN DAY SERVICE CENTER
}

\author{
坂口大史 ${ }^{* 1}$, 徳 嵩 諒*2 \\ Daishi SAKAGUCHI and Ryo TOKUTAKE
}

\begin{abstract}
Considering different spaces in elderly care facility, common space takes an important role in terms of communication and interaction. In addition, the quality of the space is closely related to the degree of satisfaction of users and almost all of the users of day service will spend a lot of time there. Based on this background, this research aims to investigate the evaluation structure of common space in day service center. As the result, 4 types of evaluation structures were revealed as the needs for "functionality", "flexibility and comfortability", "uniformity and design quality" and "a sense of unity and interaction".
\end{abstract}

Keywords : Common Space, Day Service Center, Evaluation Structure, Spatial Design, Evaluation Grid Method 共用空間, デイサービスセンター, 評価構造, 空間デザイン, 評価グリッド法

\section{1. 研究の背景と目的}

現在，日本の高齢化率は $27.3 \%$ であり，今後も高齢化が急速に進行 していくと予想されている。また，日本における高齢化率は，2060 年 には $38.4 \%$ に達し, 約 2.6 人に 1 人が 65 歳以上になると言われている ${ }^{1)}$ 。 これら高齢化率の上昇に加えて, 介護保険制度における 65 歳以上の 要介護者又は要支援者と認定された人は，2014 年度末で 591.8 万人之 なっており，2003 年度末から 221.4 万人増加している2)。上記から， 高齢者福祉施設の需要は今後も高まると予想され，利用者の施設空間 に対する潜在的なニーズを把握することは，施設における空間設計の 要素としてだけでなく, 利用者が施設で生活する上での充実した室内 環境を実現していく点で，より重要性を増すと考えられる。

高齢者福祉施設の現状として, 多床室からユニット型個室が増加 する傾向にあり ${ }^{3)}$ ，個室内においてプライバシーを開示することで, 安定的な領域を形成している ${ }^{4)}$ 。また, 入所型施設の利用者は, 入所 初期おいてプライバシーの確保された個室で滞在することが多いが, 次第に共用空間での滞在率が増える傾向にあり，共用空間は居間的

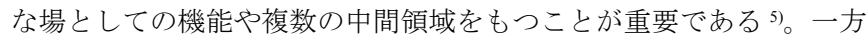
で, 通所型施設において共用空間の面積は増加傾向にあり, 利用者 の交流や団欒の場としての機能，個々の利用者の過ごし方に合わせ た柔軟な対応が必要である ${ }^{6}$ 。以上から，高齢者福祉施設の共用空間 では, 入所型と通所型で求められる機能や規模が異なるといえる。

通所型のデイサービスセンター（以下，デイとする）では，一般 的に利用人数も多く, リハビリテーションをはじめとした生活機能 向上のための機能訓練に加えて, 食事や入浴, レクリエーションな どの生活支援を目的とし, 共用空間に求められる役割が多彩である。
これらから，共用空間の内装を含めたデザインに対する評価は，施 設利用者に対して, 空間における快適性, 心地良さ, 過ごしやすさ などの心理的な影響を及ぼすと考えられる。また，利用者の共用空 間における滞在時間が長いことから，共用空間は，利用者にとって 施設の中で最も身近な生活空間の一つであるといえ，共用空間に対 する利用者の意識やニーズを把握することは意義があるといえる。

そこで, 本研究では, 様々な高齢者福祉施設における共用空間に 対する印象評価や設計要素に関する一連の研究の第一歩目として, 利用者の自立度が比較的高く, 利用者の多くが共用空間に滞在する デイを対象に，共用空間に対する評価構造を把握することで，高齢 者福祉施設における空間設計の一助と寸ることを目的とする。また, 本研究では, 共用空間に対する評価構造において, 空間の内装や設え, 空間そのものに対する欲求や機能などに関する利用者の意識を共用 空間に対する「潜在的ニーズ」として分析を行う。

\section{2. 既往研究}

デイに関する既往研究では, 利用者の行動, 家具配置, 空間利用 や運営プログラムなど様々な視点から分析が行われてきている7) 99。 また, 加藤らによるデイの場所ユニットから高齢者の移動特性につ いて分析した研究 ${ }^{10)}$, 江らによるデイの空間構成や利用者の滞在様 態について明らかにした研究 ${ }^{11)}$, 中園らによるデイの空間構成と使 われ方から施設の空間機能評価を行った研究 ${ }^{12)}$ が挙げられる。これ らデイに関する研究は，施設における利用者の行動特性や空間構成 などに着目して分析を行っているが, 利用者の意識や潜在的ニーズ

\footnotetext{
*1 日本福祉大学健康科学部福祉工学科建築バリアフリー専修 助教・博士 (学術)

*2 大和八ウス工業株) 学士(福祉工学)
}

Assist. Prof., Architecture and Barrier-free Course, Dept. of Human Care Engineering, Faculty of Health Science, Nihon Fukushi Univ., Dr.Phil.

Daiwa House Industry Company, Limited, B.Human Care Engineering 
に関する分析を行った研究はみられない。よって, 本研究はデイの 共用空間に対する利用者の印象評価から空間に対する潜在的なニー ズを分析する点で異なる立場を取っている。

次に, 内装空間に対する人々の印象評価に関する研究として, 佐 藤による居間空間における色に着目して居心地の良い構成要素を明 らかにした研究 ${ }^{13)}$, 槙による模型を用いて内装空間における光と物 体色に対する印象評価を分析した研究 ${ }^{14)}$ ，横井らによる様々な媒体 を用いて内装空間に対する印象評価の違いを考察した研究 ${ }^{15)}$ が挙げ られる。これら内装空間の色, 光, 美しさなどの印象評価に関する 一連の既往研究では, 高龃者福祉施設の共用空間に対する利用者の 潜在的なニーズを対象として分析を行った研究はみられない。

さらに，空間に対する人々の潜在的なニーズや評価構造に関する 研究として, 讃井らによる「人間 - 環境」モデルに基づいて住環境に 対する評価構造を明らかにした研究 ${ }^{16)}$, 高橋らによる写真を用いて インテリア空間に対する美的価值観の傾向を分析した研究 ${ }^{17)}$, 森永 らによるインテリア・プレゼンボードを用いた分析により, 評価構 造の類型化を行った研究 ${ }^{18)}$ が挙げられる。これらの研究では, 評価 グリッド法を用いて, 空間に対する潜在的なニーズや美しさに関す 分析を行っているが，高齢者福祉施設における共用空間に対する利 用者の潜在的なニーズの把握に評価グリッド法を適用した事例はみ られない。よって, 本研究では, 上記の研究を参考に分析を行うが, デイの利用者を対象として共用空間に対する潜在的なニーズを階層 的な論理構造として明らかにする点で異なる立場を取っている。

\section{3. 研究対象と研究方法}

本研究では，デイの利用者を対象として，共用空間の写真を用い た評価グリッド法による個別インタビューを行う。本研究で用いる 評価グリッド法は, 讃井 ${ }^{16)}$ らが開発した手法であり, 認知心理学を ベースに実験参加者の潜在的な意識やニーズを構造的に可視化する ことを目的とした個別インタビューによる調查方法である。

まず, 本研究における個別インタビューの実験参加者は, 愛知県 内において研究への協力を得ることができた $\mathrm{A} \sim \mathrm{O}$ のデイの利用者, 女性 36 名と男性 10 名の計 46 名注1) である（Table1）。

Table1 Number of Research Participant in Each Facility

\begin{tabular}{|c|c|c|c|c|c|c|c|c|c|c|c|c|c|c|c|c|}
$\begin{array}{c}\text { Faci } \\
\text { Gery }\end{array}$ & A & B & C & D & E & F & G & H & I & J & K & L & M & N & O & Total \\
\hline Female & 3 & 2 & 2 & 2 & 4 & 2 & 1 & 3 & 3 & 2 & 1 & 4 & 4 & 1 & 2 & 36 \\
\hline Male & 1 & 0 & 1 & 0 & 0 & 4 & 1 & 0 & 0 & 0 & 1 & 1 & 1 & 0 & 0 & 10 \\
\hline Total & 4 & 2 & 3 & 2 & 4 & 6 & 2 & 3 & 3 & 2 & 2 & 5 & 5 & 1 & 2 & 46 \\
\hline
\end{tabular}

次に, 個別インタビューに用いる共用空間の写真の選定を行う。本 研究で使用寸る共用空間の写真は, 通常の評価グリッド法で用いられ る「エレメント」と呼ばれるものである。また, インタビュー時は, 各エレメントに対する個別の評価は目的とせず，あくまで実験参加者 の潜在的な意識を引き出すためのトリガーという位置付けである注2)。

上記の選定手順に即して, まず, 愛知県内のデイのうち, ホームペー ジに公開されている共用空間の写真を可能な限り収集した結果, 計 257 枚選出した。続いて, 257 枚の写真を 5 名注3)によって, 空間の床, 壁, 天井の各部位における色, 素材, 質感などに加えて, 開口部や空間の
(1)

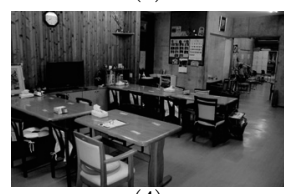

(4)
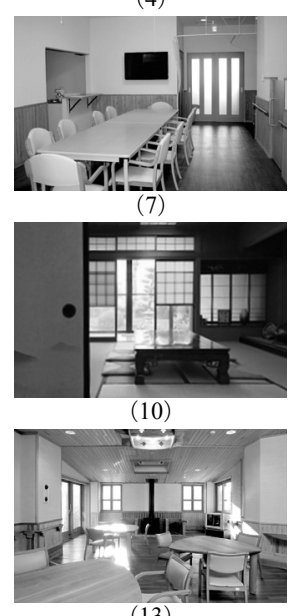

(13)

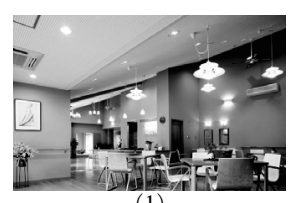

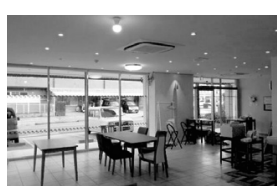

(2)

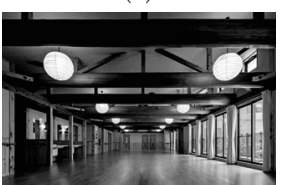

(5)

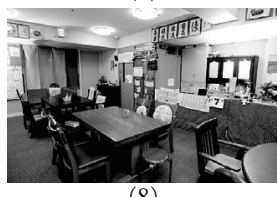

(8)

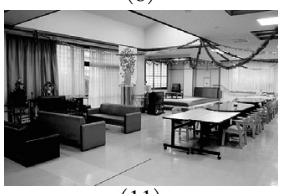

(11)

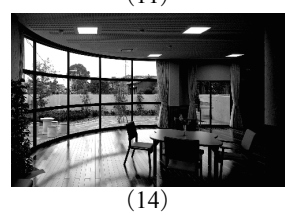

Fig. 1 Photo of Common Space

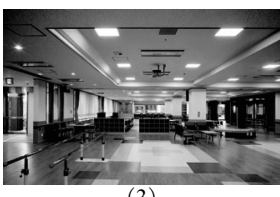

(3)

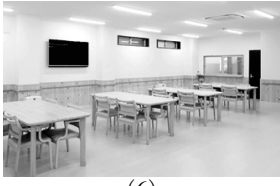

(6)

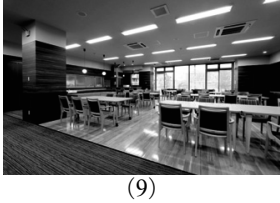

(9)

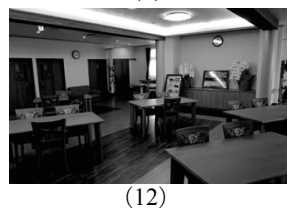

(12)

Note: The size of each photo were adjusted to same size to avoid the occurrence of misunderstanding due to the difference of the size. original. All photos in this figure ach facility. However, the contrast is as the were permitted to be published by

インテリア要素に着目してグループ分けを行った。結果として 14 グ ループが得られ，各グループの中から代表的な写真をそれぞれ 1 枚選 定して個別インタビューに用いた（Fig.1）。

本研究における研究方法として, 既往研究 ${ }^{16)}$ の方法を参考に, 上 記の写真を用いた評価グリッド法による個別インタビューを行った。 まず，本研究では，14 種類の共用空間の写真を実験参加者それぞれ の好みによって 5 グループに分類するように指示した。続いて，そ れぞれのグループに分類した際の判断理由を聞くことで，各実験参 加者がもつ潜在的なニーズを示す「評価項目注4)」を抽出した。その 後, 各評価項目からラダーリングを繰り返し行い, 各実験参加者の 階層的な評価構造を得るという通常の評価グリッド法の一連の流れ に沿ってインタビューを行った。

以下に, 本研究の流れを段階的に示す。

1）デイの利用者に共用空間の写真を提示して，それぞれの好みに よって写真を 5 グループに分類するよう指示する。

2）好み 4 位対 5 位から好み 1 位対 2 位まで各グループの比較を行 うことで，それぞれの判断理由を尋ね，評価項目として抽出する。

3）各評価項目に対して, ラダーリング注5) を行うことで上位項目, 下位項目を誘導し, 各実験参加者の評価構造を階層的に把握する。 また, 評価項目を意味内容や類似性により分類し, 分析する。

4）個人差を考慮しながら評価構造を分析するため, 上記で分類を 行った評価項目のうち，5名以上が指摘した項目を用いて数量化 III類分析とクラスター分析注 (6) を行う。その結果により, 実験参加 者の評価構造の類型化を行い, 各クラスターの評価軸を分析する。 続いて, 各クラスターにおいて評価の特徵を階層的に考察する。

5）上記のクラスター内にみられる実験参加者の個人差や特性を考 慮した分析の結果に基づき, 結論にまとめる。 


\section{4. 評価項目の抽出と分類}

評価グリッド法による個別インタビューによって各実験参加者か ら抽出した評価項目を分類し，一覧にまとめた（Table2）。

本章では，評価項目の各分類における指摘回数から，実験参加者 の共用空間に対する評価の傾向を分析するため, 各評価項目の分類 を行った。評価項目の意味内容を統一して分類を行った結果，大分 類として 5 種，小分類として 34 種を得た。

評価項目の分類の手順として, 既往研究 ${ }^{19)}$ を参考に, 著者らを 含めた 4 名によって評価項目の意味内容の統一と分類の作業を行っ た。まず，4名の合議によって各評価項目の意味内容の類似性をも とに各項目を統一した。続いて, 各評価項目を意味内容によってグ ループとしてまとめていくことで, 小分類を得た。さらに，各小分 類を包括するグループによってまとめ，大分類を得た。各評価項目 の最終的な分類は，大分類と小分類によって決定される。なお，各 評価項目の意味内容や分類を決定する際，人によって意味内容やグ ループの判断が分かれる項目については，判断の根拠を 4 名で議論 し，全員の合意が得られた時点で再び全ての項目の分類を行った。 最終的に全ての項目について，4名の判断が一致するまで分類や意 味内容の決定を繰り返し行う手順とした。
続いて, 評価項目の大分類と小分類の指摘回数による分析を行う ことで，利用者の共用空間に対する着眼点を分析する 分類した結果，空間のインテリア要素に関わる【内装】，意匠や材料 などの設計要素に関わる【設計】, 空間全体の構成や機能などに関わ る【空間】, 空間を取り巻く環境に関わる【周辺環境】, 空間による イメージや感情に関する【心象】の 5 種類に分類できた。

全実験参加者の指摘回数の傾向として,【空間】，【心象】【内装】 の順に指摘回数が多い結果となった。これより，空間における家具 や仕上げなどに加えて，空間全体の構成や明るさなどに着目しなが らも，空間全体から受ける印象やイメージに着目している。

続いて, 女性の指摘回数では, 【内装】の $\{$ 家具 $\}$,【設計】の\{部位 $\}$, 【空間】の $\{$ 明度 $\},\{$ 構成 $\},\{$ 機能 $\},\{$ 印象 $\}$, 【周辺環境】の $\{$ 景色 $\}$, 【心象】の $\{$ 安穏 $\},\{$ 満足 $\},\{$ 交流 $\}$ などの指摘回数が他の分類に比 べて多い結果となった。これより，女性は空間における机や椅子な どの家具や設計面で工夫のある部位に着目しており，さらに空間の 明るさ，構成や機能，空間から見える景色を重視している。また，空 間から感じられる落ち着きや楽しさ，他の人との会話や交流ができ る点にも着目している。女性のみが指摘した項目として,【周辺環境】 の \{気候 $\}$ や四季 $\},$ 【心象】の \{自由 $\}$ や創造 $\}$ がみられた。こ れより，女性は空間の内部環境だけでな く，空間から感じられる外部環境におけ る風や雲，四季の移り変わりなどにも着 目しており，さらに空間の自由度や空間 から感じられる創造性を重視している。

男性の指摘回数でも, 女性と同様に, 【内装】の \{家具 $\} ，$ 【空間】の $\{$ 構成 $\}$, $\{$ 機能 $\},\{$ 印象 $\}$, 【心象】の $\{$ 安穏 $\}$ な ぞの指摘回数が多い結果となった。これ より，男性も女性と同様に，共用空間に 配置される家具や空間構成，空間の機能 や空間全体の印象を重視していることに 加えて，さらに空間から感じられる落ち 着きなどにも着目している。

\section{5. 評価項目による評価構造の類型化 5.1 数量化正類分析のカテゴリースコア による軸の解釈}

評価構造の分析を行う際，全実験参 加者による評価構造では各評価項目の 繋がりが複雑化しており, 評価の傾向 を捉えるのが困難である。よって，本 章では, 評価構造を類型化することで, 評価構造の中に潜む様々な要因につい て分析する。まず, 前章で分類を行っ た評価項目のうち，5名以上が指摘した 評価項目注 8) を用いて数量化III類分析を 行い，カテゴリースコアが絶対值 1.2 以 上注9) の項目をもとに，相関係数が 0.4 以上となった第 1 軸から第 3 軸までの 軸の解釈を行う（Table3）。 
Table3 Category Score of each Evaluation Word / 表 3 各評価項目のカテゴリースコア

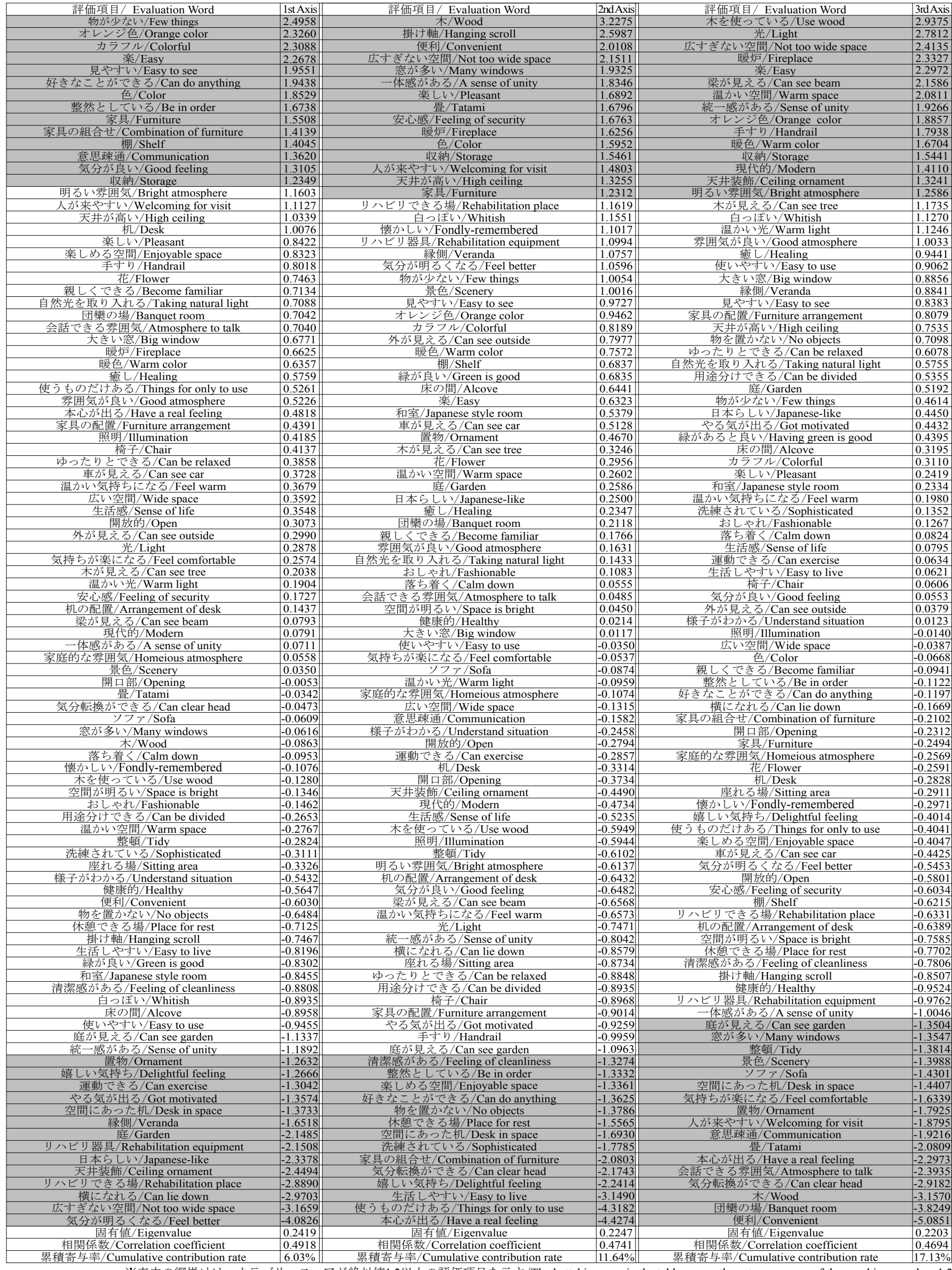
※表中の網掛けは，カテゴリースコアが絶対值1.2以上の評価項目を示す/The hattching area in the table means the category score of the word is more than 1.2 
本研究では, 数量化正類分析によって得られた軸の解釈を行う際, 各軸において特徽的な項目に着目して解釈を行う。また，各軸にお いて他の軸と類似した項目が含まれる場合も存在するが，各軸の正 負に含まれる各項目の関係性も考慮して軸の解釈を行う。

第 1 軸では, 正の值に「物が少ない,「カラフル」,「見やすい」,「色」 などがみられ，負の値に「広すぎない空間」,「リハビリできる場」,「天 井装飾」,「リハビリ器具」などの項目がみられた。第 1 軸の正にみら れる項目は，物の少なさや色などによる空間の明瞭さを示しており， 負の項目は, 照明や器具などによる空間の機能性を示していると解釈 できる。よって,第 1 軸は「視覚性 (Visuality) $\Leftrightarrow$ 機能性 (Functionality)」 を表している軸と位置付けられる。

第 2 軸では，正の值に「掛け軸」，「広すぎない空間」，「一体感が ある」,「畳」,「安心感」などがみられ, 負の值に「本心が出る」,「嬉 しい気持ち」,「気分転換ができる」などの項目がみられた。第 2 軸 の正にみられる項目は，和の要素を取り入れた空間のまとまりの良 さを示しており，負にみられる項目は，空間における楽しさや活発 さを示していると解釈できる。よって, 第 2 軸は「調和性 (Harmonicity) $\Leftrightarrow$ 活発性（Vivaciousness）」を表している軸と位置付けられる。

第 3 軸では, 正の值に「木を使っている」,「光」,「暖炉」,「温かい 空間」などがみられ，負の值に「団欒の場」「会話できる雾囲気」,「意 思疎通」、「人が来や寸い」などの項目がみられた。第 3 軸の正にみら れる項目は，木や光を取り入れることによる空間の温かさを示してお り，負にみられる項目は，共用空間での他の人との交流や会話の機会 を示していると解釈できる。よって, 第 3 軸は「温和性 (Genialness) $\Leftrightarrow$ 交流性（Interaction）」を表している軸と位置付けられる。

\section{2 クラスターの類型化と特徵}

次に, 前節において数量化而類分析から得られた実験参加者のサン プルスコアをもとに, クラスター分析を行った。クラスター分析から 得られたデンドログラムを以下に示寸 (Fig.2)。続いて, クラスター 分析によって得られたデンドログラムを等しい類似度で区切ることに より, クラスターの類型化を行う。デンドログラムの結果から，4つ のクラスターが得られた。さらに, 各クラスターにおける評価の特徵 を捉えるため, 第 1 軸と第 2 軸, 第 1 軸と第 3 軸によるサンプルスコ アの二次元散布図をそれぞれ作成し（Fig.3，4)，各クラスターにおい て軸に対するカテゴリースコアの平均值が絶対值 0.5 以上となった軸 に着目して，共用空間に対する評価軸について分析を行う。

散布図におけるクラスター 1 の位置をみると,「機能性（-0.979）注10)」 の軸寄りに位置したことから，共用空間における家具や設えによる 機能性を求めるクラスターであると考えられる。散布図におけるク ラスター 2 の位置をみると,「活発性 $(-1.217) 」 と 「$ 交流性 $(-0.555) 」$ の軸寄りに位置したことから，クラスター 2 は共用空間において能動 的に行える活動や他の人との交流を求めるクラスターであると考えら れる。散布図におけるクラスター 3 の位置をみると,「視覚性 $(0.537) 」$ と「温和性 (0.966)」の軸寄りに位置したことから, クラスター 3 は 共用空間の色や家具による空間の明快さや温かみのある空間を求め るクラスターであると考えられる。散布図におけるクラスター 4 の 位置をみると，「調和性（1.146）」と「交流性（-1.645)」の軸寄りに 位置したことから，クラスター 4 は共用空間における部位やインテ リアによる空間全体の調和や他の人とのコミュニケーションを通じ た交流を求めているクラスターであると考えられる。

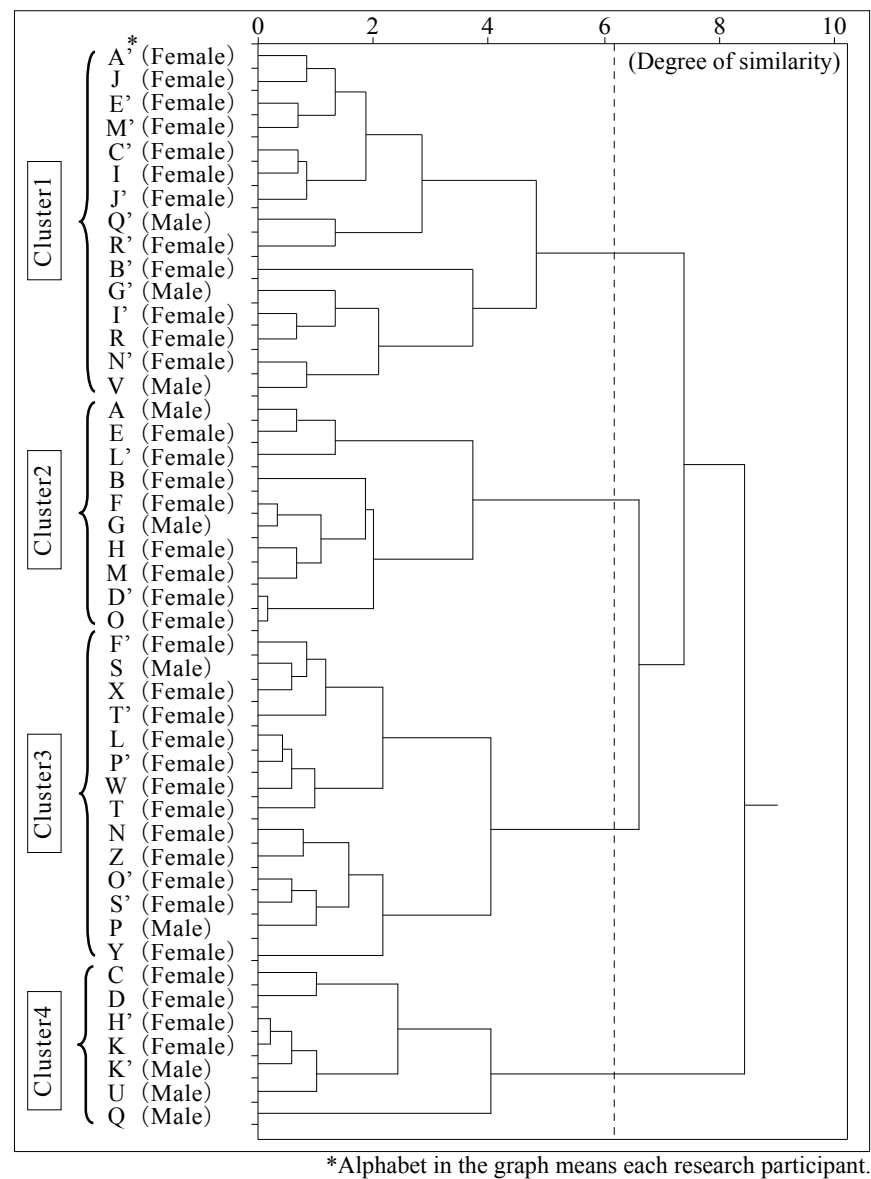

Fig. 2 Dendrogram from Cluster Analysis

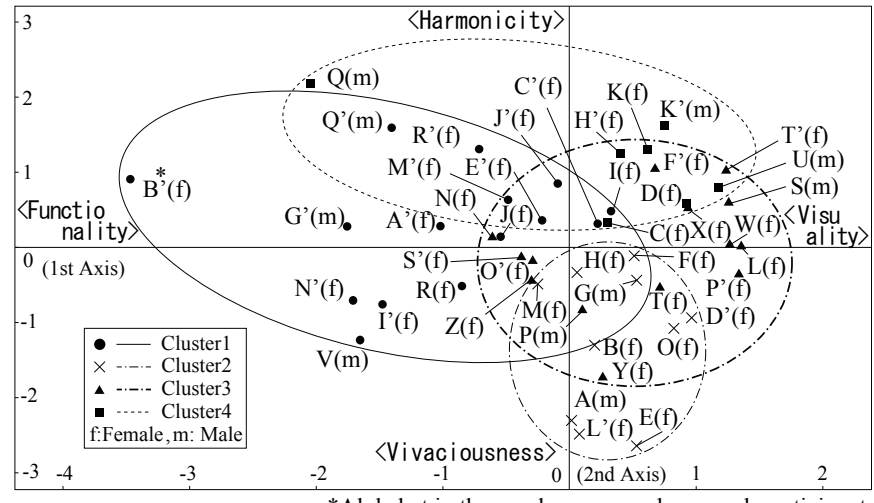

*Alphabet in the graph means each research participant.

Fig. 3 Scatter Graph of 1st-2nd Axis of Sample Score

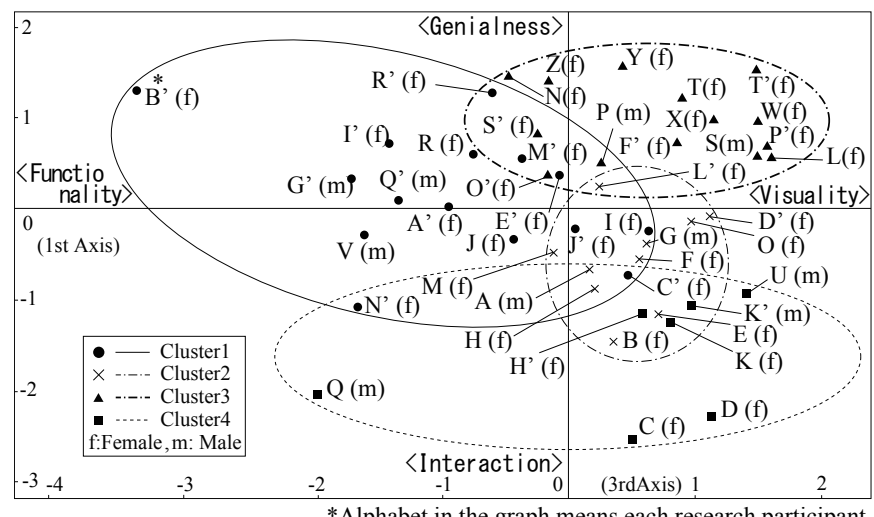

Fig. 4 Scatter Graph of 1st-3rd Axis of Sample Score 


\section{6. デイサービスセンターにおける共用空間に対する評価構造}

本章では，各クラスターにおける共用空間に対する評価構造から 評価の傾向やクラスターでの共通点や相違点を考察する。まず，複 雑にネットワーク化された評価構造を分析するため，各クラスター について傾向が読みとれた軸におけるカテゴリースコアが，絶対值
1.2 以上である評価項目を基準として階層的な繋がり注11)を図示した 評価構造図をクラスター毎に作成した（Fig.5）。作成した評価構造に 基づいて分析を行う際，各クラスターの特徵をより明確に把握する ため，基準とした評価項目に関連する項目については，クラスター 内の複数の実験参加者が指摘した項目に絞って分析を行った。

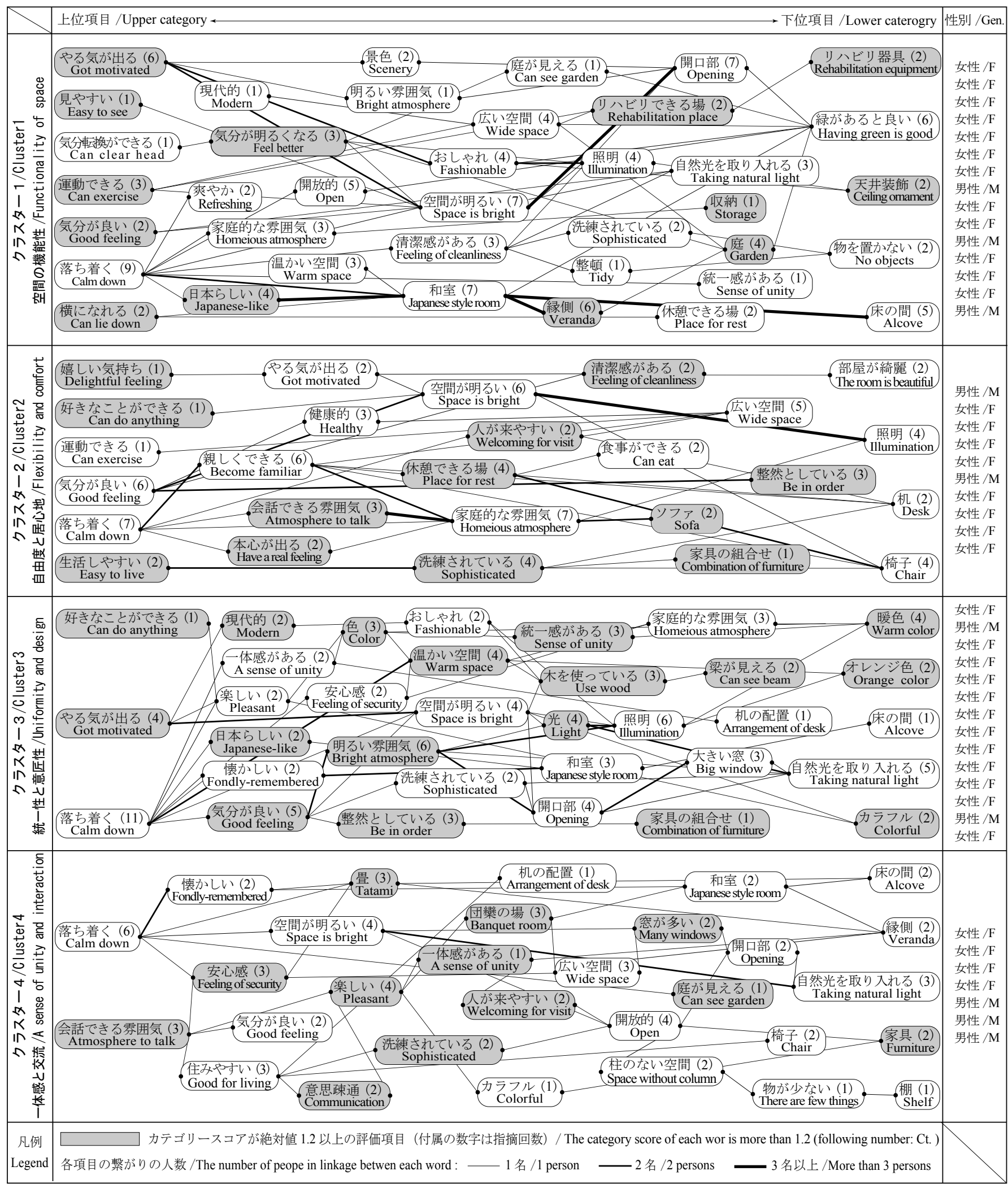

Fig. 5 Evaluation Structure in each Cluster / 図 5 クラスター別の評価構造 


\section{1 クラスター別の評価の傾向}

本節では，各クラスターにおける特徵的な項目や各項目同士の繋 がりに着目することで，クラスター毎の評価の傾向を考察する。

クラスター 1 では，上位項目に「やる気が出る」，「見やすい」，「運 動できる」,「横になれる」などがみられ, 下位項目に「リハビリ器具」, 「天井装飾」,「収納」,「リハビリできる場」などがみられる。これよ り, クラスター 1 に属する実験参加者は, 空間における器具や収納 などによる空間の機能性を評価している。また，中位項目における 「温かい空間」や「清潔感がある」などの項目が示すように, 空間か ら感じられる温かさや清潔さを評価している。クラスター 1 におけ る特徴的な項目として, 下位項目にみられる「床の間」や「縁側」は, 「和室」や「日本らしい」へ繋がることから，日本の伝統的な様式を 取り入れた和の空間を評価している。さらに，下位項目の「緑があ ると良い」や「庭」が「広い空間」一繋がることから，緑や庭など の外部環境を取り込むことで空間の開放性を求めている傾向が読み とれる。以上から，クラスター 1 は，和や外部環境を取り入れた空 間の機能性を評価しているクラスターであると考えられる。

クラスター 2 では, 上位項目に「好きなことができる」,「気分が良 い」,「生活しや寸い」などがみられ，下位項目に「照明」,「椅子」,「ソ ファ」などがみられる。これより，クラスター 2 に属する実験参加者 は，照明を含めた椅子やソファなどが充実していることによる，空間 の自由度の高さや活動のしや寸さを評価している。また，下位項目 に「机」や「椅子」が見られる一方で「整然としている」がみられる ことから，余分な物がなくバランスの取れた空間を求めているといえ る。クラスター 2 における特徵的な項目として, 中位項目にみられる 「人が来や寸い」,「休䕀できる場」,「家庭的な䨌囲気」は「親しくで きる」,「会話できる雾囲気」,「本心が出る」などに繋がることから， 人が集まりやすく, 自然な会話ができて自宅のようにくつろぐことの できる空間を評価している傾向が読みとれる。以上から，クラスター 2 は, 空間における家具や照明などのバランスによる自由度の高さと 居心地の良さを評価しているクラスターであると考えられる。

クラスター 3 では, 上位項目に「やる気が出る」,「現代的」,「温 かい空間」などがみられ，下位項目に「暖色」，「梁が見える」，「才 レンジ色」,「カラフル」などがみられる。これより, クラスター 3 に属する実験参加者は, 色を含めた意匠の面から空間におけるデザ イン性や温かさを評価している。また, 中位項目における「光」や「明 るい雰囲気」などの項目が示すように，空間に光を取り込むことで 空間の明るさを評価している。クラスター 3 における特徽的な項目 として，下位項目にみられる「暖色」や「梁が見える」は「統一感 がある」や「木を使っている」に繋がり，さらに「おしゃれ」など に繋がることから，空間の色や自然素材の木を用いるなど，空間の デザインの統一性や意匠性の高い空間を評価している傾向が読みと れる。以上から, クラスター 3 は, 色や素材による空間の統一性と 高い意匠性を評価しているクラスターであると考えられる。

クラスター4では, 上位項目に「会話できる雰囲気」,「安心感」,「住 みや寸い」などがみられ，下位項目に「机の配置」,「縁側」,「家具」 などがみられる。これより, クラスター 4 に属する実験参加者は, 机, 椅子, 棚などの空間における家具の配置や自然と触れ合える場所に よって, 安心して生活できる空間を評価している。また, 中位項目 における,「意思疎通」,「楽しい」,「団欒の場」などの項目が示すよ
うに，他の人との会話や交流ができる触れ合いの場を評価している。 クラスター 4 における特徵的な項目として, 下位項目にみられる「縁 側」や「家具」は「一体感がある」や「開放的」一繋がることから， 外部環境が感じられる広さのある空間でありながらも，一体感のあ る空間を評価している傾向が読みとれる。以上から, クラスター 4 は, 家具配置や部位による空間の一体感と交流を評価しているクラ スターであると考えられる。

\section{2 各クラスターにおける評価の比較考察}

前節に続いて, クラスター間で共通する項目や各項目同士の繋が りから, クラスター毎の評価における相違点や共通点を考察する。

全てのクラスターにおいて「落ち着く」，「空間が明るい」，「洗練 されている」が共通してみられた。まず, 「落ち着く」について, ク ラスター 1 では「日本らしい」や「和室」などから繋がり，クラス ター2では「親しくできる」や「本心が出る」などから繋がる。また， クラスター 3 では「温かい空間」や「気分が良い」などから繋がり, クラスター4では「懐かしい」や「安心感などから繋がる。これより, クラスター 1 は和を取り入れた空間，クラスター 2 は家庭のように 過ごせる空間, クラスター 3 は温かみのある快適な空間, クラスター 4 は馴染みがあり安心できる空間から落ち着きを評価している。続 いて,「空間が明るい」について, クラスター 1 と 3 では「照明」,「自 然光を取り入れる」などが「空間が明るい」に繋がることから，人 工照明と自然光をバランスよく取り込んだ空間の明るさを評価して いる。一方で，クラスター 2 では「照明」から繋がり，クラスター 4 では「自然光を取り入れる」から繋がることから，人工照明と自 然光をそれぞれ評価している。さらに,「洗練されている」について, クラスター1では「物を置かない」から繋がり,クラスター 2 では「家 具の組合せ」から繋がる。また，クラスター 3 では「開口部」から 繋がり，クラスター4では「開放的」から繋がる。これより，クラ スター 1 は空間における物の少なさ, クラスター 2 は配置する家具, クラスター 3 は開口部の種類や大きさ, クラスター 4 は空間におけ る開放感から空間における洗練性を評価している。

クラスター 1,2 において「清潔感がある」が共通してみられた。ク ラスター 1 では「整頓」や「自然光を取り入れる」などから繋がるこ とから, 家具や置物が整理されている点や光の取り入れ方によって清 潔感を評価している。また, クラスター 2 では「部屋が綺麗」から繋 がることから，物理的な綺麗さによって空間の清潔感を評価している。 クラスター 1,3 において「温かい空間」が共通してみられた。クラス ター 1 では「和室」から繋がることから, 空間における和の要素によっ て温かさを評価している。また, クラスター3では「オレンジ色」,「木 を使っている」，「家庭的な雰囲気」から繋がることから，色や素材に 加えて, 空間から感じられる家らしさによって温かさを評価している。 クラスター 2,3 において「整然としている」が共通してみられた。ク ラスター 3 では「家具の組合せ」から繋がることから, 配置される家 具の構成によって空間の整然さを評価しており, 最終的に両クラスター において「気分が良い」へ繋がることから，整然さから空間の快適性 を評価している。クラスター 3,4 において「一体感がある」が共通し てみられた。クラスター3では「色」や「机の配置」から繋がること から，空間の色や机の配置のバランスによって空間の一体感を評価し ている。また，クラスター4では「縁側」から繋がることから，室内 と縁側を通じた外部との連続性によって空間の一体感を評価している。 


\section{7. 結論}

本研究では，デイの利用者に対する個別インタビューを行うこと で, 共用空間の家具, 照明, 開口部, 自然光などの空間の要素に加えて, 機能や室外の庭や景色に関する潜在的なニーズを得ることができた。

空間における機能性に関寸る評価構造では，空間に配置される器 具や収納などの設えだけでなく, 和の要素を取り入れた空間や緑や 庭などの外部との繋がりをもった開放感のある空間を評価していた。 また，空間における自由度の高さと居心地の良さに関する評価構造 では，照明や家具が整然と配置されていることで活動がしやすく， 自分の家のようにくつろぐことのできる空間を評価していた。空間 における意匠性に関する評価構造では, 空間を構成する色, 素材, 自然光などの要素による空間の明るさや温かさに加えて, 統一感が ありデザイン性の高い空間を評価していた。さらに，空間の一体感 や交流に関する評価構造では, 室内の家具配置や室外の庭との連続 性による安心感や他の人と触れ合える㕰いの空間を評価していた。

各クラスターで共通する評価項目から，空間内における物の少な さや家具の配置による整然さに加えて，空や大きな開口部によって 広さを感じられる点から, 空間の洗練さを評価していた。また, 人 工照明と自然光の組合せによる明るさを評価する一方で，人工照明 と自然光のそれぞれを重視している傾向もみられた。これらは，空 間における光の捉え方が多様であることを示しており，上記の空間 の洗練さと合わせて, 室内照明の位置や照度, 空やドアをはじめと した開口部の具体的な位置や大きさ，室内に配置する家具の数，大 きさ，位置を含めた詳細な検討の必要性が明らかとなった。

さらに, 家具の構成や配置による空間全体のまとまりや室内の空 から見える庭や景色などの外部環境が感じられ，内部と外部の中間 領域となる縁側を通じた室内外の連続性を重視しており，空間の開 放性や安心感を評価している傾向もみられた。これは，共用空間で 滞在している間に外一出る機会の少ない利用者にとって, 空間内部 のみならず周辺環境を含めた外部との繋がりも意識した一体感のあ る設計が求められていることを示唆している。

今後の課題として, 養護老人ホーム, 特別養護老人ホーム, 介護 老人保健施設, 老人福祉センターなどの高齢者福祉施設を対象とし て，各施設の共用空間に対する潜在的なニーズの把握や，それぞれ の共用空間に対する分析結果の比較考察も含めた研究を蓄積してい く予定である。その際，利用者の状態に合わせた新たな調査方法の 開発や介助者のもつ潜在的なニーズの把握の必要性も指摘される。 また，共用空間の設計に関する具体的な要素である，空間に配置す る家具や開口部の具体的な数, 大きさ, 位置に加えて, 室外環境と なる庭も含めた詳細な分析を行っていくことが今後の課題である。

\section{謝辞}

本研究を進めるにあたり, 調查を受け入れて頂いたデイの皆様, 限られた時間の中でインタビューにご参加頂いた利用者の方々には, 本研究において多大な御協力を頂きました。また，本研究における 調查や論文作成において, 五十里一志氏（日本福祉大学健康科学部 4 年), 白井翼氏（日本福祉大学健康科学部 4 年), 藤沢玲衣氏（積水 八ウス株式会社）に御協力を頂きました。文末ではありますが，こ こに記して感謝申し上げます。なお, 本研究は, 「2017 年度日本福祉 大学健康科学研究所研究助成」の補助を受けて行いました。

\section{注}

注 1） 本研究における実験参加者数では，男女の割合が男性 $22 \%$, 女性が $78 \%$ であった。内閣府の資料 ${ }^{20)}$ から，介護保険制度のサービスを受給 した 65 歳以上の被保険者は，男女の割合でみると男性が $29.2 \%$ ，女性 が 70.8\% となっている。よって，本研究における男女の割合も，上記 の統計資料と同程度の割合となっていることから，利用実態に即した 形で調査を行うため，恣意的に男女比を操作することはしなかった。

注 2）参考文献 ${ }^{16)}$ １8), 21) に基づいて実験に用いる写真の選定を行った。評価 グリッド法におけるエレメントの選定について, 実験目的に応じてエ レメントの数, 提示方法, 比較方法等は実施者の裁量によるとされて おり，写真を用いる場合，一定の撮影角度や視点距離によらず，可能 な限りパターンを網羅するように選び出すこととされている。上記に 基づき, 本研究では, 空間の仕上げ, 家具, 開口部, 照明など各写真 に写り込んでいる様々な要素を基に, 撮影角度や焦点距離を考慮して 実験に用いる写真のバリエーションの確保を目的として選定を行った。

注 3）建築設計や建築計画を専門とする者 4 名, 社会福祉学を専門とする者 1 名により，共用空間の写真に関する分類と選定を行った。

注 4）本研究では，個別インタビューによって，実験参加者が共用空間に対 して自発的に指摘した項目を評価項目と定義する。

注 5） インタビューにおいてラダーリングを行う際，通常の評価グリッド法 と同じく, インタビュアーは聞き役に徹し, 実験参加者の回答を誘導 しないように注意した。また，回答を深追いして実験参加者がその場 しのぎの回答をしないように留意した。なお，評価項目においてマイ ナスのイメージが出た場合は，プラスのイメージで回答するように実 験参加者に依頼することで各評価項目を抽出した。

注 6）本研究におけるデータ分析では, 統計解析ソフト「エクセル統計 2015」を用いた。また，数量化林類分析では， 5 人以上が指摘した項 目と各実験参加者による $0 / 1$ 型データを用いた。クラスター分析を実 行した際の設定は, 階層型 - 凝集法による個体分類とし, 距離計算は ユーグリッド距離，合併後の距離計算はward 法を採用した。

注 7）なお，本研究における実験参加者の男女比に差があるため，本章では, 各分類における男女の比較考察は行わなかった。

注 8） 5 名以上が指摘した評価項目は，一定以上の実験参加者が指摘した項 目かつ, 相反する評価項目や複数の評価項目との多様な繋がりを示し た項目であった。よって, 評価構造に潜在する共通点や相違点を考察 するにあたり，5名以上が指摘した評価項目を用いて分析を行った。

注 9）一般的に，カテゴリースコアの絶対值が高いほど，評価項目と実験参 加者の関連が強いと考えられる。本研究では, 複雑化した評価構造を 類型化して分析するため, 評価の傾向が把握できる基準として, カテ ゴリースコアの絶対值 1.2 を設定して分析を行った。

注 10）各クラスターの軸に対するカテゴリースコアの平均值を示す。

注 11） Fig.5 で示寸評価構造では，各実験参加者が回答した項目から順にラダ ーアップを行うことで上位項目，ラダーダウンを行うことで下位項目 を抽出しており, 各実験参加者が述べた順に項目を記載している。図 中の評価項目同士の繋がりを示寸線は，その項目同士の順番を含めた 繋がりとその繋がりを指摘した人数を表している。また，各項目間の 線の距離については，限られたスペースにて日本語と英語の併記を行 い, かつ可能な限り図が見やすくなるように整理した結果として生じ たものであり, 線の長短に重要度の差異等の意味はない。なお, 評価 グリッド法における個別インタビューにより抽出される評価構造では, 一般的に下位項目には, より客観的で具体的な事項が位置し, 上位項 目には，より抽象的な価值判断に関する項目が位置する。

\section{参考文献}

1) Cabinet Office: Chapter1. Section1. Status of Elderly People, Koureika Hakusho 2017, http://www8.cao.go.jp/kourei/whitepaper/w-2017/html/gaiyou/s1_1.html (in Japanese)(accessed 2018.5.18) 内閣府 : 第 1 章 高齢者の状況（第 1 節）, 平成 29 年版高齢社会白書, 2017.6

2) Cabinet Office: Chapter1. Section2. Current Status and Trend of Elderly People and Surrounding Environment, Koureika Hakusho 2017, http://www8.cao. go.jp/kourei/whitepaper/w-2017/gaiyou/pdf/1s2s_03.pdf (in Japanese)(accessed 2018.5.18)

内閣府 : 第 1 章 高齢者の姿と取り巻く環境の現状と動向（第 2 節）, 平成 29 年版高齢社会白書, 2017.7

3) Ministry of Health, Labour and Welfare : 104th Meeting Documentation1, A Subcommittee of Social Security Evaluation Meeting Nursing Care Benefit 社会保障審議会介護給付費分科会, 第 104 回,資料 1 (改), 2014.7 
4) Tachibana, H., Toyama, T. and Takahashi T.: A Study on "Activity in Place" of Elderly Residents in Nursing Home : Studies on Spatial Structure of Nursing Home with Private Rooms 1, Journal of Architecture, Planning and Environmental Engineering (Transactions of AIJ), Vol.63, No.512, pp.115-122, 1998.10 (in Japanese)

橘弘志 , 外山義, 高橋鷹志 : 特別盖護老人ホーム入居者の施設空間に展開寸 る生活行動の場, 日本建築学会計画系論文集, 第 512 号, pp.115-122,1998.10

5) Inoue, Y.,Toyama, T., Otaki, K. and Ohara, K.: A Study on the Personalization of Residents in Nursing Home : Studies on Social Welfare Institution for the Elderly from the Aspect of Dwelling 1, Journal of Architecture, Planning and Environmental Engineering (Transactions of AIJ), Vol.62, No.501, pp.109$115,1997.11$ (in Japanese)

井上由紀子, 外山義, 小滝一正, 大原一興 : 高齢者居住施設における入居者 の個人的領域形成に関寸る考察 : 住まいとしての特別養護老人ホームのあ り方に関する研究 その 1 , 日本建築学会計画系論文集, 第 501 号, pp.109$115,1997.11$

6) Kim, S., Takemiya, K. and Tamamitsu, S. : Use of Multifunctional Services and Architectural Space in a Small-Scale Multifunctional Long-Term Care Facility for the Elderly, Journal of Architecture and Planning (Transactions of AIJ), Vol.81, No.730, pp.2595-2604, 2016.12 (in Japanese)

金聖龍, 竹宮健司, 玉光祥子 : 小規模高齢者介護施設における多機能开 一ビスと施設空間の利用特性, 日本建築学会計画系論文集, 第 730 号, pp.2595-2604, 2016.12

7) Sugawara, M., Aizawa, H. and Aiba, Y. :Space Arrangement for Day-Service Center Seen from the Elderly Activities, Journal of Architecture and Planning (Transactions of Aij), Vol.69, No.585, pp.39-45, 2004.11 (In Japanese)

菅原麻衣子, 藍澤宏, 相羽康宏 : 高齢者の主体的活動の展開からみた通所 施設の空間整備, 日本建築学会計画系論文集, 第 585 号, pp.39-45, 2004.11

8) Bojo, N., Yamada, A. and Ueno, J. : Investigation on the Programs and the Activ-ities of the Elderly at Day Service Centers in Tama-City, AIJ Journal of Technology and Design. No.22, pp.409-414, 2005.12 (in Japanese) 坊上南海子, 山田あすか, 上野淳 : 多摩市における高齢者デイサービスセ ンターの運営プログラム・活動の実態と利用構造, 日本建築学会技術報告 集, 第 22 号, pp.409-414, 2005.12

9) Ito, S., Ueda T., Mizuno, Y., Yamazaki, S., and Katsumata, H: A Study on the Change of Furniture Arrangement in Day Room and the Factor in Changes: the Formation of Activities in Place and the Space Structure in Day-Service Center, Journal of Architecture and Planning (Transactions of AIJ), Vol.78, No.686, pp.775-782, 2013.4 (in Japanese)

伊藤朱子, 上田哲也, 水野祐輔, 山崎敏, 勝又英明 : デイルームにおける 家具配置の変化とその要因についてーデイサービスセンターの場の形成 と空間構成 その 1 - , 日本建築学会計画系論文集, 第 686 号, pp.775-782, 2013.4

10) Kato, Y.and Mori, K.: An Analysis of Place Trip by Place Units in Day-Service Centers for the Elderly, Journal of Architecture and Planning (Transactions of AIJ), Vol.69, No.583, pp.17-22, 2004.9 (in Japanese)

加藤悠介, 森一彦 : デイサービスセンターにおける場所ユニットからみた 高齢者の場所移動分析, 日本建築学会計画系論文集, 第 583 号, pp.17-22, 2004.9

11) Chiang, WJ.,Tsukada, H., Fujii, Y., Okamoto, K. and Nishide, K.: A Study on Space Composition and Users' Social Behaviors in Toyama-Style Day Care Service Centers -A Study on the Regional Harmonious Care Home-, Journal of Architecture and Planning (Transactions of AIJ), Vol.77, No.675, pp.987-994, 2012.5 (in Japanese)

江文菨, 佃悠, 藤井容子, 岡本和彦, 西出和彦 : 富山型デイサービスにお ける空間構成と利用者のかかわりに関寸る研究一地域共生ケアホームに 関する研究一, 日本建築学会計画系論文集, 第 675 号, pp.987-994, 2012.5

12) Nakazono, M.,Mishima, S., and Yamamoto, S.: Space Utilization of Day Service Facilities Renovated from Traditional Timber Houses : Provision of Welfare Facilities for the Aged in Rural Areas, Case Study on Abu Town Yamaguchi Prefecture, Japan(Part 2), Journal of Architecture and Planning (Transactions of AIJ), Vol.79, No.696, pp.491-499, 2014.2 (in Japanese)

中園眞人, 三島幸子, 山本幸子 : 木造民家を再利用した高齢者デイサービ 又施設の空間構成と使われ方一農山漁村地域における高齢者福祉施設整 備に関する研究 : 山口県阿武町を対象としてその 2 - , 日本建築学会計 画系論文集,第 696 号, pp.491-499, 2014.2
13) Sato, M.: Effects of Interior Colors on Comfort in a Living Room, Journal of Environmental Engineering (Transactions of AIJ), Vol.76, No.668, pp.897-902, 2011.10 (in Japanese)

佐藤仁人 : 居間のインテリアにおける色彩の居心地に及ぼす影響, 日本建 築学会環境系論文集, 第 668 号, pp.897-902, 2011.10

14) Maki, K.: The Influence of Object Color and Lighting Color on the Impression of Interior, Journal of Environmental Engineering (Transactions of AIJ), Vol.77, No.676, pp.461-466, 2012.6 (in Japanese)

槙究 : インテリアの印象に及ぼす光色と物体色の影響, 日本建築学会環境 系論文集, 第 676 号, pp.461-466, 2012.6

15) Yokoi, A. and Saito, M.: A Comparison of Evaluation among Different Media Stimulation of Housing Space, The Japanese Journal of Psychology, Vol.87, No.3, pp.294-302, 2016.5 (in Japanese)

横井梓, 齋藤美穂 : 居住内装空間における刺激媒体別の印象評価比較, 心 理学研究, 第 87 巻, 第 3 号, pp.294-302, 2016.5

16) Sanui, J. and Inui, M.: Phenomenological Approach to the Evaluation of Places : A Study on the Construct System Associated with Place Evaluation : 1, Journal of Architecture, Planning and Environmental Engineering (Transactions of AIJ), No.367, pp.15-22, 1986.9(in Japanese)

讃井純一郎, 乾正雄 : レパートリー・グリッド発展手法による住環境評価 構造の抽出: 認知心理学に基づく住環境評価に関する研究 (1), 日本建築学 会計画系論文報告集, 第 367 号, pp.15-22, 1986.9

17) Takahashi, H. and Oi, N.: The Aesthetic Sense of Values and Evaluation Structure in Interior Space : Fundamental Research on Sense of Beauty in Architectural Space of Today's Japanese People, Journal of Environmental Engineering (Transactions of AIJ), Vol.72, No.615, pp.59-64, 2007.5

高橋浩伸, 大井尚行 : インテリア空間における美的価值観と評価構造 : 現 代日本人の建築空間における美意識に関する基礎的研究, 日本建築学会環 境系論文集, 第 615 号, pp.59-64, 2007.5

18) Morinaga, C., Oi, N. and Takahashi, H.: Categorization of Evaluation Construct and Individual Attributes through Evaluating Presentation Boards of Interior: A Study about Evolution and the Transformation of the Sense of Values about the House Environment, Journal of Environmental Engineering (Transactions of AIJ), Vol.76, No.666, pp.633-639, 2011.8 (in Japanese)

森永智年, 大井尚行, 高橋浩伸 : インテリア・プレゼンボードの評価を通 した評価構造と個人属性の類型化 住環境に関する価值観の進化と変容に 関する研究, 日本建築学会環境系論文集, 第 666 号,pp.633-639, 2011.8

19) Sakaguchi, D.,Shibata, C., Sakai, F. and Kitagawa, K.:Latent Selective Factor of Japanese Design Professionals and Laymen through Analysis of Cognitive Structure of Wood for Interior Finnish Design Professionals and Laymen, Journal of Architecture and Planning (Transactions of AIJ), Vol.80, No.715, pp.20212031, 2015.9 (in Japanese)

坂口大史, 柴田智菜美, 坂井文也, 北川啓介：内装用木材の認知構造から みる潜在的選択要因, フィンランドの設計専門家と非専門家を対象として, 日本建築学会計画系論文集, 第 715 号, pp.2021-2031, 2015.9

20) Cabinet Office: Chapter1. Section3. Health and Social Welfare of Elderly People, Koureika Hakusho 2016, http://www8.cao.go.jp/kourei/whitepaper/w-2016/ zenbun/pdf/1s2s_3_2.pdf (in Japanese)(accessed 2018.1.18) 内閣府 : 第 1 章 高齢者の健康と福祉（第 3 節）, 平成 28 年版高齢社会白書, 2016.7

21) Tsujimura, S. :The evaluation grid method (EGM)" to elicit a structured evaluation hierarchically, The Journal of Acoustical Science and Technology Vol.73, No.12, pp.783-789, 2017 (in Japanese) 辻村壮平：階層的に構造化された評価を引き出すための評価グリッド法， 日本音響学会誌, 第 73 巻, 第 12 号, pp.783-789, 2017 


\section{EVALUATION STRUCTURE OF COMMON SPACE IN DAY SERVICE CENTER}

\section{Daishi SAKAGUCHI ${ }^{* 1}$ and Ryo TOKUTAKE*2}

${ }^{* 1}$ Assist. Prof., Architecture and Barrier-free Course, Dept. of Human Care Engineering, Faculty of Health Science, Nihon Fukushi Univ., Dr.Phil. ${ }^{* 2}$ Daiwa House Industry Company, Limited, B.Human Care Engineering

\section{Introduction}

The rate of aging in Japan has been rising and the current rate is $27.3 \%$. As the expectation, the rate will reach $38.4 \%$ in 2060 and the number of users of elderly care facilities will also increase in the future. Considering different spaces in the facility, common space takes an important role for the users in terms of communication and interaction. The existing research also reports that the quality of common space is closely related to the degree of satisfaction of the users and almost all of the users in day service center will spend a lot of time in common space. Based on this background, the evaluation structure of common space in day service center was investigated through the individual interviews for the users.

\section{Material \& Method}

This study included 14 different types of interior photos of common space. These photos were collected from the website of each day service center in Aichi prefecture in Japan. This research was also conducted using evaluation grid method. As a first step, 46 participants (36 female and 10 male) divided interior photos into 5 groups according to their preference. Following that, each group was evaluated and the factors for the evaluation were asked until the participants stopped answering. From the result of the interview, 5 large classifications and 34 small classifications were obtained as the evaluative words. These words were analyzed by mathematical quantification theory class III and cluster analysis.

\section{Result \& Discussion}

As a consequence of cluster analysis, 4 clusters were obtained. Cluster 1 needs for the functionality of space taking in Japanese style and the external environment. The feature in cluster 2 was seen as the need for the flexibility and comfort of space by the balance of equipment in space. In cluster 3, the participants require uniformity and design quality by color and material of space. Cluster 4 needs for a sense of unity and interaction realized by the arrangement of furniture and individual parts in space.

Comparing the common evaluation words in each cluster, the difference in the evaluation of calmness, brightness, and sophistication of space could be observed. In the evaluation of the calmness of space, for instance, cluster 1 evaluated the calmness from the Japanese element and cluster 2 evaluated from the homely atmosphere. On the other hand, cluster 3 evaluated the calmness from the warmness of space and cluster 4 evaluated from familiarity and relief to space. In the evaluation of brightness, cluster 1 and 3 evaluated the brightness of space from both artificial and natural right. Cluster 2 evaluated the brightness from artificial right and cluster4 evaluated natural right. Regarding the sophistication of space, cluster1 evaluated the sophistication from the less stuff condition and cluster2 evaluated from the combination of furniture. Unlike cluster 1 and 2, cluster 3 evaluated the sophistication from the number and size of opening and cluster4 evaluated from the openness of space.

\section{Conclusion}

As the result, 4 types of evaluation structures were revealed as the needs for "functionality", "flexibility and comfortability", "uniformity and design quality" and "a sense of unity and interaction". In further research, a similar study will be conducted on common space in different kinds of elderly care facilities such as nursing home and geriatric health services facility and those results will be compared to realize the ideal common space to improve the quality of life of users. 